\title{
SOME NOTES ON ECOPHONETICS: THE PROBLEM OF SOUND DISTINCTIVENESS, SOUND SUSTAINABILITY, AND THE SUSTAINABILITY OF VOWEL SYSTEMS IN CONTACT CONDITIONS AS EXEMPLIFIED BY THE STANDARD POLISH VOWEL SYSTEM IN CONTACT WITH THE KASHUBIAN VOWEL SYSTEM
}

\begin{abstract}
In the paper, an assumption is forwarded that if sound systems are brought to a contact setting, inter-entity distinctiveness is usually distorted. In the psycholinguistic sense of the word, it means that in the perception process, a particular sound of a less favoured system may be downgraded or even ridiculed. This generally places a given sound system in a weaker position sustainability-wise. It is assumed that the process may involve the presence and operation of the phenomenon of ethnic nepotism.
\end{abstract}

KeYwords: universal sound space; inter-entity distinctiveness index; contact setting; negative/positive bias towards sounds; social dominance orientation; ethnic nepotism

\section{Introduction}

The main ecological claim that is made here proposes that natural language sound inventories are directly related to an aspect of the communicative environment, that is, the speaking environment. In particular, it is suggested that the existing sound inventories (cf. Maddieson 1984 for an unparalleled data base) are constructed according to two well-defined ecological principles. One of them states that human sounds are distributed within the universal sound space (i.e. the space which is available to all the human communicators). The other states that the human sounds are organized (i.e. distinctive feature-orchestrated) in the form of structural-functional chunks, referred to as 'phonetic entities' and produced within the vocal-auditory modality. Furthermore, these entities are the foundation of phonological (sound) systems and are thus allowed

Stanisław Puppel - Uniwersytet im. Adama Mickiewicza, Poznań, spuppel@amu.edu.pl 
to persist in the 'universal sound space' (henceforth USS) owing to their distinctiveness/discreteness which is of two types: inter-entity (i.e. inter-sound) distinctiveness and subsequent intra-entity (i.e. intra-sound) distinctiveness. Both types of sound distinctiveness work synergistically, that is, through external sound synergy and internal sound synergy, towards the maintenance of the individual phonetic entities in the USS.

However, if sound systems are brought to contact (e.g. in formal instructor-controlled foreign language teaching/learning practices), inter-entity distinctiveness may be (and usually is) distorted in the sense that a particular phonetic entity may be downgraded or even omitted and ridiculed (i.e. stigmatized) by the learners, which would automatically constitute a grave barrier to a full acceptance of a given sound system by a particular foreign language learner (or even an entire group of learners).

Thus, a given system may be regarded by the communicators as less favourable and therefore weaker on the 'sustainability scale' (which is organized in a dichotomous way, i.e. 'most sustainable - least sustainable') as opposed to a system which is perceived as more favourable and therefore stronger on the sustainability scale. In this particular case, it is argued that communicators, speakers of standard Polish, while perceiving some Polish nonstandard dialects, including the regional Kashubian language, tend to downgrade and ridicule some of their structural (i.e. distinctive) characteristics, especially as regards their vowel systems. This perceptual-subjective judgment may, in turn, appear to be detrimental to the sustainability of these dialects in the standard Polish sound space as a subset of the USS.

\section{Inter-entity distinctiveness and inter-entity distinctiveness index}

If a particular phonetic entity is regarded as a kind of a functional 'organism' which exists in the universal space of the communicators as embodied agents and which is the source of order and regularity (cf. Sober 1991; Diefenbeck 1995), then the inter-entity distinctiveness of any particular sound may be likened to organismal distinctiveness. This distinctiveness may then be understood as pertaining to the tendency of maintaining their strong individuality/identity and system member reliability (cf. Thoft-Christensen 1987; Gould 2002). In the narrow confines of the USS, this individuality/identity and system member reliability is obtained through the functioning of what may be called the 'inter-entity distinctiveness index' (henceforth IEDI) to which every human communicator-speaker has access and which allows to be used in audio-vocal (oral) natural language manifestations. In other words, the inter-entity distinctiveness index is part and parcel of every human communicator's phonological-phonetic competence.

IEDI is of a partially bio-psychological and partially social-cultural nature. Its bio-psychological nature is derived from the mental (i.e. underlying) distinctiveness of any phonetic entity stored in the individual communicator's long-term mental space/ 
representation (cf. Martin and Caramazza 2003; Hunt and Worthen 2006) and expressed via the workings of the audio-vocal modality, while its social-cultural character is derived from the sound's successful functioning in the social-cultural (i.e. public and negotiable) space which is most naturally connected with its ethnic membership and colouring. Needless to say, the inter-entity distinctiveness index contributes to the integrity and stability of a given sound system. One may now ask the following general question: How is IEDI established? A brief answer is proposed below.

\section{Establishing the inter-entity distinctiveness index}

Establishing the inter-entity distinctiveness index requires a process, also referred to as 'first language acquisition', which is best understood as a synergistic sequence of complex operations performed by the communicator on at least two levels, namely: (a) on the biological-mental (psychological) level of the individual communicators, and (b) on the social (public)-cultural level. Both levels are involved in a sequence of long-term operations which comprise the following:

- making choices in the universal sound space, that is, choosing between the production of the optimal (i.e. quantal) and non-optimal (i.e. non-quantal) sounds (here vowels) in the quantal areas of the USS (cf. Stevens 1972; Stevens 1989; Perkell and Cohen 1989; Puppel 1992; Puppel and Jahr 1997),

- achieving focus/distinctiveness/discriminability/discreteness of the (motor-articulatory) entities,

- achieving individual skillfulness in sound entity perceptibility,

- achieving social acceptance of sound entity perceptibility, that is, acceptance by other members of a given social group. In this case, one may state that a given sound entity acquires a marked degree of social acceptability load,

- achieving stationarity (stability) of sound entities in the sound system,

- achieving sustainability of the particular sound entities, that is, prolonged cross-generational social-cultural (ethnic) existence of the sound entities in the USS. It may also be termed the overall ecological 'fitness' of the particular sound entity,

- communicating sound entity distinctiveness in audio-vocal (oral) communications.

\section{Bringing the inter-entity distinctiveness index of sound systems to a contact setting}

While languages go into a contact situation (cf. Weinreich 1968), and more precisely, their sound systems are confronted with each other in cross-linguistic contact, that is, the L1 (or dialect 1) - L2 (or dialect 2) contact-learning setting, some kind of a mental subcategorization (or valuation) takes place in the learning process. As a result, some 
of the phonetic categories present in a local dialect may be perceived as less favourable and socially and culturally less acceptable and therefore more prone to the functioning of some kind of an affective filter expressed through social-cultural disdain (and even rejection) and some kind of socially-controlled hesitation to be maintained in the sound space of a given ethnic community.

It is argued here that this is what may happen in the perception of some of the vowel characteristics present in local Polish dialects and the regional Kashubian language by the users of the standard dialect of Polish when the respective vowel systems are brought to contact in the Natural Language Global Arena (NaLGA, see e.g. Puppel 2011 for a discussion of the term).

In other words, in the contact situation, a clearly suppressive, or, levelling nature on the part of the standard dialect users, may be demonstrated, both on the level of mental characterization (e.g. expressed through disdain, ridicule, derision and even rejection of certain phonetic features/traits), in which case one may even talk of what has been known in pertinent literature on the problem of ethnicity as 'ethnic nepotism' (see e.g. Vanhanen 1999; 2012; 2014; Salter 2007), and in a more narrow sense on the level of purely bio-mechanical adjustments realized through the reduction (i.e. levelling) of certain phonetic features to more optimal ones which follow from the mechano-inertial properties of the articulatory system (see e.g. Lewis 2002).

Furthermore, on the level of mental categorization, a given sound system (e.g. a vowel system) may be perceived as supported by a set of what may be called 'value propositions', both positive and negative, developed and applied by the perceiving human communicator (human communicating agent). In this case, a positive/negative value proposition attached to a given sound entity may turn out to be the main driver behind a positive/negative perception of a given phonetic parameter (feature, trait) and may, in case a negative value is selected, thus govern the communicator's further decision to show a form of stigmatization, for example, disdain towards it and, subsequently, lead to its rejection either in the course of the foreign language learning process or quite simply in a mere dialect-to-dialect comparison made by the communicators.

In what follows, the suppressive/levelling nature of the optimal vowel system of standard Polish will be described following a brief characterization of optimality. The latter may be defined as the criterion which minimizes the total weight of a system subject to the presence of certain constraints. In such a system, optimality criteria play the most crucial role in its design. Subsequently, some vowel systems which occur in the USS may be defined as optimal systems. The standard Polish six-entity/unit vowel system is a very good example of an optimal sound design, that is, an optimal vowel system, which follows from the fact that it happens to be constructed according to the ecologically relevant optimality criteria (cf. Prager 1968) based on systemic homogeneity and physiological-articulatory integration. The ecologically relevant optimality criteria comprise the following: 
- a functional minimum (or near minimum) number of entities which contribute to what has been called the 'minimum-weight design of structural elements' (cf. Patnaik et al. 1995),

- a small (minimum) number of design variables which maintain the system's overall fitness, especially in contact condition, as well as secure the individuality of the particular entities,

- a general stationarity constraint superposed on the minimum number of sound entities which constitute any optimal vowel system, including the standard Polish six-entity/unit vowel system.

\section{Inequalities in value proposition attachment to selected vowel types in the optimal-non-optimal vowel system setting}

As has been indicated above, the human communicating agents (henceforth HCAs) may demonstrate a tendency towards applying negative value propositions (or applying stigmatization, see Trudgill 1991) with respect to selected vowel entities, especially when a particular HCA happens to be a native user of an optimal (or near optimal) vowel system. This is the case with the Polish HCAs who acquire and are equipped with the following six vowel system:

$\begin{array}{lll}\mathrm{i} & & \mathrm{u} \\ & \mathrm{i} & \\ \mathrm{e} & & \mathrm{o}\end{array}$

and who, while confronted with the Kashubian language whose non-optimal nine unit/ entity vowel system (see e.g. Topolińska 1967; Topolińska: 1974; Vandel 2004; Jocz 2013 ) contains the following vowel entities:

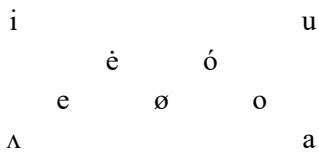

may be negatively biased towards some of its design/salient features applied in some morphological contexts. In particular, it refers to the following characteristics of the Kashubian vowel system:

- the feature complex of 'closed' and 'front/tense' vowel [i], which in Kashubian is used instead of the 'semi-closed' and 'front' vowel [i] , as exemplified in standard Polish [sin] (syn), which in Kashubian is pronounced as [sin],

- the 'central' and 'neutral/lax' vowel [ə/ø] (schwa) which in some Kashubian pronunciations replaces the standard Polish [i], as exemplified by the word ryba ([riba]), pronounced in Kashubian as [rəba]. 
In order to check the presence of the negative bias towards the above mentioned features of the Kashubian vowel system, the author conducted a small experiment in which a questionnaire was used. 20 respondents, all linguistically untrained speakers of standard Polish, aged 25-40, listened to the audio-recorded pronunciations of [sin] and [roba], and were next asked to answer the following question:

What adjectives would you attach to the Kashubian pronunciations [sin] (syn) and [rəba] $(r y b a)$ ?

(Jakich przymiotników/określeń uży/a/tby Pan/Pani w odniesieniu do kaszubskiej wymowy polskich wyrazów: syn [sin] i ryba [rəba]?)

The following adjectives were proposed: zabawny (funny), nie do przyjęcia (unacceptable, improper), dziwny (strange), and their distribution was as follows:

[sin] - it was regarded as funny and as unacceptable in all 20 cases,

[rəba] - it was regarded as funny in all 20 cases and as unacceptable in all 20 cases, and in addition it was regarded as strange in 20 responses.

The results obtained may be presented by means of the following diagram:

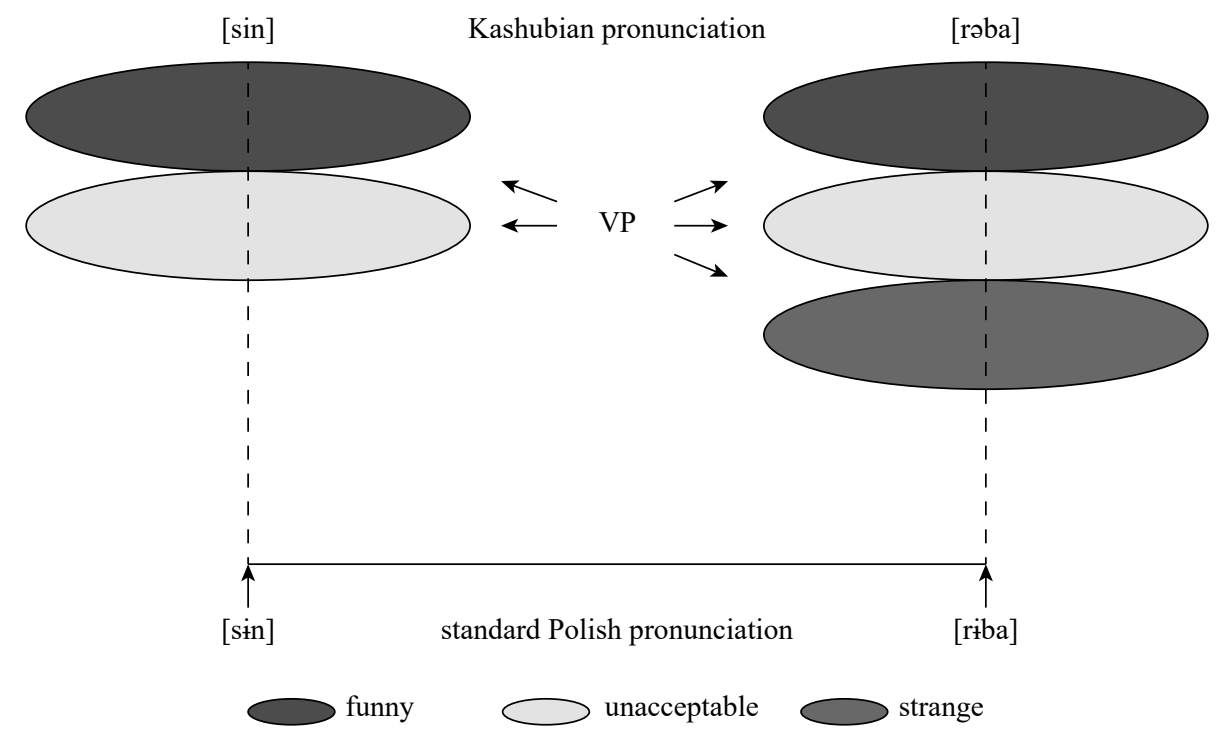

Figure 1: Value propositions (VP) at work (for details, see text above)

Thus, it follows from this very simple experiment that the perception and subsequent valuation of some of the Kashubian vowels by the communicators who speak standard Polish does indeed show the presence of the operational validity of the suppressive/ levelling mechanism underlying the nature of the optimal vowel system of standard Polish in contact with other non-standard dialects of Polish or possible regional minority languages (here the Kashubian language). 
Obviously, the presence of this mechanism in the standard language communicator competence, as exemplified by the preliminary experimental data demonstrated above, testifies to the fact that a particular non-standard dialect which operates in the NaLGA together with the other (regional) dialects may be at a loss with regard to the reception and social acceptance of some of its characteristic/salient features, especially on the phonological-phonetic plane. This fact may, in turn, contribute to the dialect's reduced 'robustness' (see Puppel 2007) and may thus exert a negative influence on the dialect's (or regional language's) sustainability vis-à-vis the standard dialect(s) on the sustainability scale as described above.

Finally, the experimental results referred to above, though scanty and preliminary as they are at this very moment, do indicate the presence and functioning of a psychological mechanism of 'social dominance orientation' (see Sidanius and Pratto 1999), which supports the overall mental-social-cultural functioning of both a particular sound design and of the particular sound units on the social-cultural level.

If viewed in the context of ecological sustainability of the particular natural languages/dialects, the above described mechanism of social dominance orientation, fed by ethnic nepotism, may contribute to shedding some more light on the phenomenon and generation of inequalities, linguistic insecurity, and social-cultural stratifications which may occur among natural languages/dialects in the contact setting and may, subsequently, assist in accounting for the occurrence and generation of any possible social inequalities and stigmatization with regard to the phenomenon of natural language/dialect sustainability on the sustainability scale. In this particular case, the generation of inequalities has been limited to the standard Polish vowel system versus the Kashubian regional language vowel system in a contact setting where the former is perceived as more favourable by members of the Polish community and the latter as less favourable.

\section{References}

Diefenbeck, James A. (1995): A subjective theory of organism. Lanham: University Press of America. Gould, Stephen Jay (2002): The structure of evolutionary theory. Cambridge, Mass.: Harvard University Press. Hunt, R. Reed/Worthen, James B. (eds.) (2006/2012): Distinctiveness and memory. Oxford: Oxford Scholarship Online.

Jocz, Lechosław (2013): System samogłoskowy współczesnych gwar centralnokaszubskich. Lipsk.

Lewis, Rebecca J. (2002): "Beyond dominance: the importance of leverage". The Quarterly Review of Biology 77.2., 149-164.

Maddieson, Ian (1984): Patterns of sounds. Cambridge: Cambridge University Press.

Martin, Alex/Cramazza, Alfonso (eds.) (2003): The organization of conceptual knowledge in the brain: neuropsychological and neuroimaging perspectives. A special issue of the journal Cognitive Neuropsychology. New York: Taylor and Francis.

Patnaik, Surya N./Guptill, James D./Berke, Laszlo (1995): "Merits and limitations of optimality criteria method for structural optimization". International Journal for Numerical Methods in Engineering 38.18., 3087-3120. 
Perkell, Joseph S./Cohen, Marc H. (1989): "An indirect test of the quantal nature of speech in the production of the vowels /i/, /a/, and /u/". Journal of Phonetics 17, 123-133.

Prager, William (1968): "Optimality criteria in structural design". Proceedings of the National Academy of Sciences, USA. Applied Physical Sciences 61.794-796.

Puppel, Stanisław (1992): "Construction of vowel systems in the universal vowel space: some typological remarks". NORDLYD. Tromsø University Working Papers on Language and Linguistics 18. 1-14.

Puppel, Stanisław/Jahr, Ernst Hakon (1997): "Theory of Universal Vowel Space and the Norwegian and Polish vowel systems". In: Hickey, Raymond/Puppel, Stanisław (eds.): Language history and linguistic modelling. A festschrift for Jacek Fisiak on his 60 th birthday. Berlin: Mouton de Gruyter. 1301-1321.

Puppel, Stanisław (2007): "Tężyzna języków naturalnych" (The robustness of natural languages). In: Chałacińska-Wiertelak, Halina/Kropaczewski, Krzysztof (eds.): Dyskurs wielokulturowy. Prace Humanistycznego Centrum Badań. Łódź: Drukarnia i Wydawnictwo PIKTOR. 7-15.

Puppel, Stanisław (2011): "The universal natural language preservation mechanism: an ecological approach". Transkomunikacja. W stronę sprofilowania przestrzeni publicznej jako wielopłaszczyznowej przestrzeni komunikacyjnej. Scripta de Communicatione Posnaniensi. Seria: Prace Naukowe Katedry Ekokomunikacji UAM. Poznań: Zakład Graficzny. 91-99.

Salter, Frank (2007): On genetic interests: family, ethnicity, and humanity in an age of mass migration. New Brunswick, N.J.: Transaction Publishers.

Sidanius, Jim/Pratto, Felicia (1999): Social dominance: an intergroup theory of social hierarchy and oppression. Cambridge: Cambridge University Press.

Sober, Elliott (1991): "Organisms, individuals, and units of selection". In: Tauber, Alfred I. (ed.): Organisms and the origins of self. Dordrecht: Kluwer Academic Publishers. 275-296.

Stevens, Kenneth N. (1972): "The quantal nature of vowels: evidence from articulatory-acoustic data". In: David, Edward E./Denes, Peter B. (eds.): Human communication: a unified view. New York: McGraw-Hill. 51-66.

Stevens, Kenneth N. (1989): "On the quantal nature of speech". Journal of Phonetics 17, 3-45.

Thoft-Christensen, Palle (ed.) (1987): Reliability and optimization of structural systems. Berlin: Springer-Verlag.

Topolińska, Zuzanna (1967): "Teksty gwarowe centralnokaszubskie z komentarzem fonologicznym". Studia z Filologii Polskiej i Stowiańskiej 7, 88-125.

Topolińska, Zuzanna (1974): A historical phonology of the Kashubian dialects of Polish. The Hague: Mouton. Trudgill, Peter (1991): "Language maintenance and language shift". International Journal of Applied Linguistics 1.1., 61-69.

Vandel, Patricia S. (2004): Prospects for an endangered language: the effects of stigmatization, group sentiment and standardization movements on the future of the Kashubian language. New Haven, CT: Yale University, Department of Linguistics.

Vanhanen, Tatu (1999): Ethnic conflicts explained by ethnic nepotism. Stamford, CN: JAI Press.

Vanhanen, Tatu (2012): Ethnic conflicts: their biological roots in ethnic nepotism. London: Ulster Institute for Social Research.

Vanhanen, Tatu (2014): "Ethnic nepotism as a cross-cultural background factor of ethnic conflicts". Open Journal of Political Science 4, 143-155. Published online in SciRes: http://www.scirp.org/journal/ojps

Weinreich, Uriel (1968): Languages in contact: findings and problems. The Hague: Mouton Publishers. 